\title{
Juan Bautista Antonelli: the first example of Alicante's bastioned fortifications
}

\author{
A. B. González Avilés, M. I. Pérez Millán \\ \& A. L. Galiano Garrigós \\ Department of Building Construction, University of Alicante, Spain
}

\begin{abstract}
Juan Bautista Antonelli, one of the most important engineers of Felipe II's reign, was the first engineer who proposed a bastioned fortification project for the city of Alicante. The reforms were motivated by the continual attacks from Turkish and Berber pirates. The walls of Charles $\mathrm{V}$ were soon obsolete by the development of artillery. The Antonelli's fortification project was drafted in 1563 and paid attention to both attack by sea as a possible attack from the inside. The city was perfectly defended with four new fortified bastions and three demi-bastions. The old walled city concept had been forgotten. The project's interpretation allows us to trace its hypothetical design and find the source of the XVII century proposals fortress. The project was never built and the city defence systems relied upon Santa Barbara's castle for protection. One hundred and twenty five years later, in 1688, Ambrosio Borzano proposed a bastioned fortification project for the city of Alicante. As a result of his project only the bastion of San Carlos was built. Keywords: Antonelli, architecture, military engineers, Alicante, fortification, defensive walls.
\end{abstract}

\section{Introduction}

The first modern fortification that the Alicante stronghold boasted was the walls of Charles V. The works were carried out in two phases under command by the Duke of Calabria. The first, that took place between the years 1530 and 1535, was to fit turrets or fortified towers around the medieval walls. New towers were built at the end points of the city, San Francisco, San Bartolomé and San Sebastian, and two flanking the new access to the dock, called Nuestra Señora de Monserrate. The new towers protected artillery and provided a refuge point under the walls of its defence system. In 1546, after a considerable delay, work was completed on 
the walls. After the bulk of the work was completed, only the parapets, some stone encasing and the new trench in the fortification between La Puerta de la Huerta to La Puerta de Elche remained to be finished. (In 1999, the archaeological intervention by Cophiam in the Rambla de Méndez Núñez, prior to the implementation of the storm drain project 'Proyecto Antirriadas', documented the existence of the trench under the wall of Vall and its width was four metres from the tower of San Francisco.)

From that point in 1546 onwards, the city of Alicante boasted a "triple defensive ring" [1, p. 47].

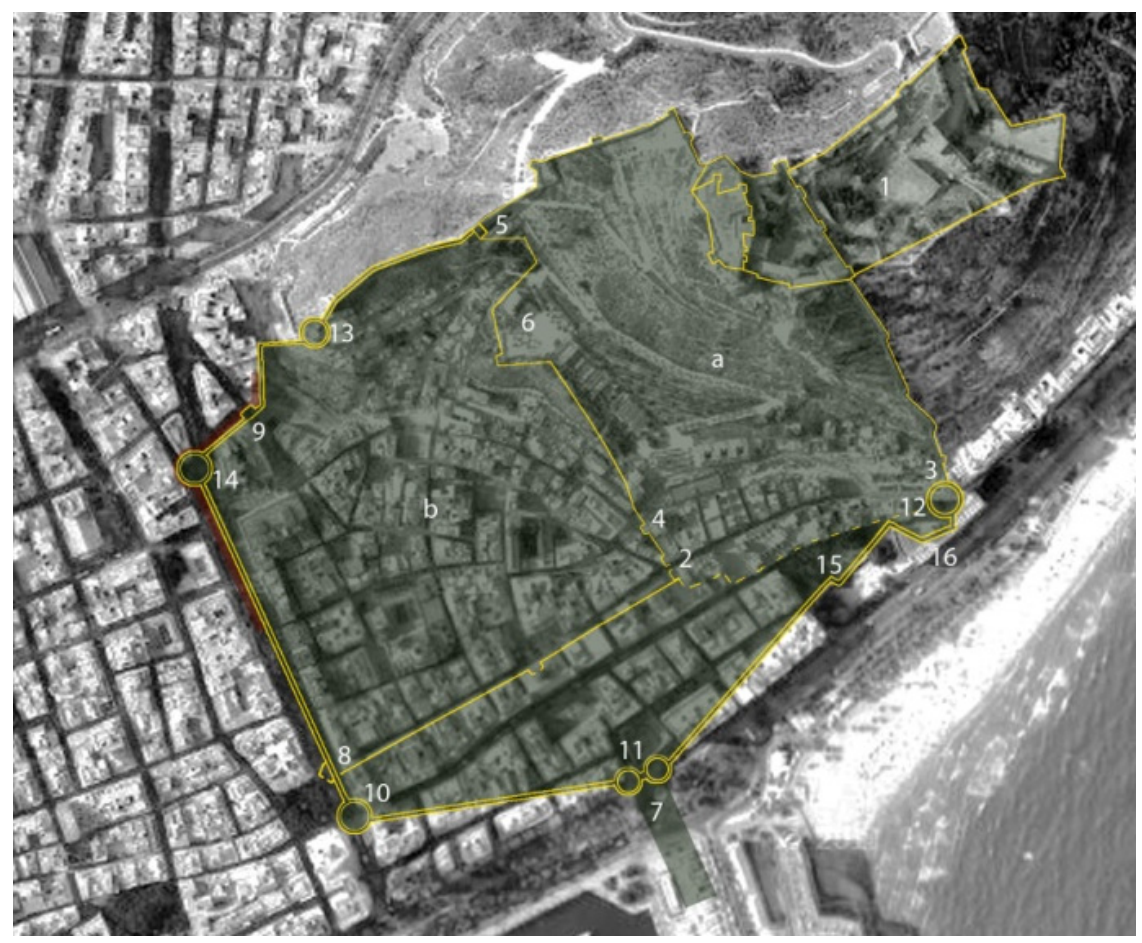

Figure 1: Authors' map. The city of Alicante with a "triple defensive ring" that existed in $\mathrm{XVI}^{\mathrm{e}}$ drawn on present day city. a. Villa Vieja; b. Villa Nueva; 1. Castillo de Santa Bárbara; 2. Puerta de Ferrisa; 3. Puerta Nueva; 4. Torre de la Pólvora; 5. Torre de Mig Armut; 6. La Ereta; 7. Puerta del Muelle; 8. Puerta de Elche; 9. Puerta de la Huerta; 10. Torreón de San Bartolomé; 11. Torreones de Ntra. Sra. de Monserrate; 12. Torreón de San Sebastián; 13. Torreón de la Ampolla; 14. Torreón de San Francisco; 15. Galería de la Plaza de Ramiro; 16. Plataforma del Esperón i de Sta. Bárbara. 
In the memorial of 1551 sent by Villarasa to Prince Felipe, the city of Alicante was described as "greatly strengthened" [2]. Similarly, in the memorial of 1552, concerning the defence of Guardamar and Alicante, it was made known that Alicante, at this time, was a well fortified city. However, the works during the sixteenth century did not create a new enclosure to protect housing around the access points near to La Puerta de Elche and La Puerta de la Huerta, which were developed in this century. Growth was pushed up towards the waterfront, leaving a large number of extramural houses divided into two suburbs, whose expansion throughout the century impeded the stronghold's defence. (The layout of that which was carried out appears for the first time in the only preserved fortification project in Alicante from the seventeenth century, the Castellón and Valero project of 1688 [3].)

The fortification of Charles V soon became obsolete with the development of new artillery and its destructive power. There had been a need to strengthen and renovate the new defensive fortification in Alicante, while also concentrating on the Castle of Santa Barbara's fortification. Given the continuity of pirate attacks off the coast, by mainly Turkish and Berber pirates, the king was forced to call upon military engineers such as Calvi, the Fratín and Antonelli.

\section{Antonelli's fortification project}

Juan Bautista Antonelli was of course one of the most important royal engineers of Felipe II. (To know more about his biography, see [4].) Along with his younger brother Baptista and his nephew Cristóbal, they were the most important engineers in service to the Spanish Monarchy in the sixteenth century. On $9^{\text {th }}$ March 1581, Francés de Álava even put on record in Lisbon that Antonelli and Fratín had been the most prestigious engineers of the time. ("The people I know in the service of Spain Majesty, in addition to Fratin and Antonelli, are Jorge Setara who is resisting in Perpignan, Baptista Antonelli, the brother of Antonelli who lives in Peñiscola and Christopher Antonelli, his nephew, at present in Barcelona, and Tiburcio who was sent for Your Majesty to Fuenterravia and Phelipe Third who resides in Lisbon. All of them are foreign and no one Spanish.". Boira Maiques [5].)

Antonelli participated in numerous projects; by visiting, advising on, and project managing almost all fortifications of interest within the Spanish Empire, including those across the Atlantic. He left his mark on Alicante, Orihuela, Benidorm, Peñiscola, Palma de Mallorca, Cartagena, Tortosa, Valencia, and more. He understood the peninsula as if it were a fortress, whose perimeter encompassed Spanish coasts and borders; the "ports" were the doors and the "places" (or fortresses) were the bastions. By fortifying the peninsula, the Spanish Empire became "the summit of where no other empire has been before" [6].

It comes as no surprise that Felipe II said that Antonelli "would visit these marinas again" [7]. The task set called for visits to all castles and marinas to design their fortifications and coordinate what must be done to them [7]. He set about immediately, and Antonelli, accompanied by grand master of Valencia, toured the 
coastline visiting Alicante in 1562. In a letter addressed to the king, he described it articulately:

"Plaças [fortified towns] in this coast are all very weak and generally have thin walls with no ramparts or defensive walls, with small and castellated parapets and small towers, and lacking in trenches for the most part; those that are there are very few (...)" [8].

On the topic of Alicante he specifically said "I have noticed something lacking about these round turrets they have (...) slanted ramparts and dug out trenches in the parapets. And with so many homes in a suburb near the walls, this hinders the defence" [9]. When he visited the first time around, he was there to inspect and had not yet produced a draft design for the fortification. Therefore, on $27^{\text {th }}$ August 1562, Felipe II, through an address to the justice and jurors in city of Alicante, required his services again [10].

The result of this was that the memorial of January 1563. In a draft design Antonelli highlighted special importance of wall and dock fortifications, to combat threats from Turkish and Muslim attacks, which were the most threatening at the time. The other priority was the wall around the neighbourhood of San Francisco and the demolition of any impeding obstacles. First proposal was the implementation of powerful defences, some high above the trenches, finally barrages, trenches and counterscarps. In the memorial of $23^{\text {rd }}$ January 1563 , signed by Juan Bautista Antonelli and grand master of Valencia, these works were outlined.

The first part of this outlines the defences of each of the front walls, mounted ramparts, trenches and access points. First, the bastion of San Felipe was to be built and attached to the Puerta de Elche. Then, the bastion of Santiago would need to be constructed, linking its left flank with the existing front wall all the way up to the new one. On the San Antón side, the right flank, would need to join the La Puerta de Huerta entrance. Thirdly a new bastion, called San Antón would need to be built. As with what usually happened in other fortified enclosures, once these defences were implemented, they would all conjoin together. The work to follow envisaged the building of a new stronghold from the entrance to docks, named San Juan. Subsequently, the implementation of two partial bastions, San Andres and Santa Ana, and behind them a third stronghold named San Sebastian [11]. The joining of the barrages between bastions allows us to understand the order of each arrangement. The process of the defence works were: Santa Ana, San Antón, Santiago, San Felipe, San Juan and San Andrés. The joining of two bastions means San Andrés and San Sebastián were not documented, and neither was one of the flanks on the Santa Ana side. This further cements our previous statements that Antonelli brought the rocky bases of Santa Ana and San Sebastián closer together, which leads us to suggest the possible location was at the ends of the enclosure, on both sides of Benacantil.

In total there were four new bastions and three partial ones. For the first time the stronghold of San Sebastian, whose location had improved bastions in the east described years ago up by the Duke of Calabria as "Viego" (old) [12]. At the top there would be conjoined fortifications every forty spans, and later rising to fiftyfive. The memorial described the outline of the works of the defence, the walls, 
mounted ramparts and trenches, considering different options depending on whether the soil was too rocky or not, or if there was a supply of water. The construction system used, same as that of the Duke of Calabria used in his last memorial, was the method of fortifying walls. It sought to sure up rock work in places where the presence of water would be a problem, substituting the wall with masonry to replace a one flooded by water. Sloped walls were to be implemented, of five spans in thickness. Now that there was water present both in part near the sea and in the ravine in Canicia, the mud walls were raised. At ground level on the inside of the walls there were ventilation systems, at twenty spans apart, to divert water away from the rampart. To divert the water, drainage systems with iron gratings were used where necessary [13].

Antonelli continued with his work on the city walls, with the first being San Felipe. This fort was to be the most important and, most likely, its gunfire would've been able to sweep across the bay and Babel beach. Its significance is not only reflected in the importance of being the first, but also in his name, no doubt in honour of King Philip II. Similarly in the late seventeenth century the stronghold of San Carlos was developed, under Charles II, the most important stronghold for the city in the history of the fortifications of Alicante.

In the description of the trenches, the most important of which was to be able to widen the divide in the western side, from the bastion of Santiago up to the sea in order to obtain water, created a lot of security. Alternatively, there should have been a small trench through the middle to be able to obtain water at the very least. The figure below shows the possible draft of the section Antonelli carried out similar to that of 1598 that comprised the outline of the fortification by Cristóbal de Rojas. Based on fortification treaty and that of Jean Errard of Bar-Le-Duc in 1583 [14], we can hypothesize the design of the floor plan.

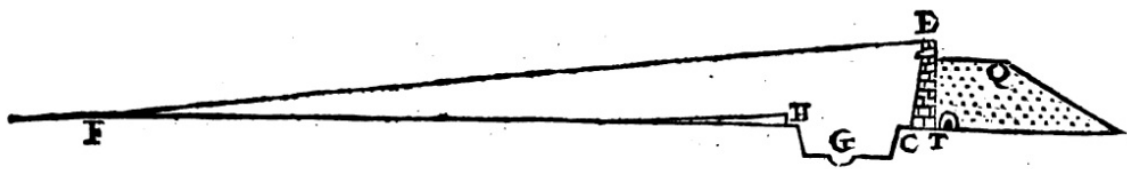

Abecedario en doclanacion defte perfil:

C.F. Diftancia de la defenfa, defde la cafama- T. Boca de la contramina de alra y anchẹ.6.P.

tahafta la efquina del valuarte. Goo.pies. Q. Verdadero rerrapleno, fin la murslla. so.P:

C.E. Altura do la twunilla,y defenfa. 4s.pies. H. Eftrada cubierta, tienc de ancho. is.pies.

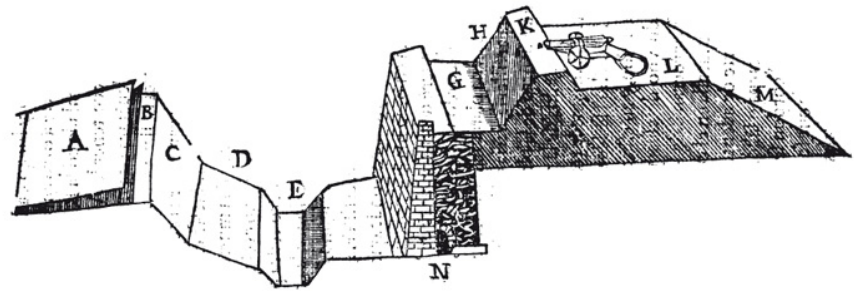

A Efcarpa de tierra de la ef. trada cubierta a la cápaña Joo.p

B La mefma eftrada.16.pies.

C Eared del cotrafollo. 25 . p.

E Elrefelio. So.pics:

F Altura dela muralla biesta

C El Elacio entrecl cauallero

y el parapeto de la cortina.

$\mathrm{H}$ Altura del cauzllero. 12.P.

K Rarapeto del cauallero.14. P.

L. Il mefino cauallero.

M Lafubida al cauallero.

N. A Puerta a la contramina.

Figure 2: $\quad$ Profile fortification [15]. 
On the eastern side, the wall below the castle that also comprised of a trench and borrowed stone were to be used in the docks and in other works throughout the city [16]. Finally, Antonelli proposed all doors were to be wooden with spiked gating on the outside and that the use of drawbridges would allow access to the city [17].)

Having described the works carried out, according to which we can get an idea of the magnitude of the project, Antonelli highlighted further issues in his memorial: the demolition of the houses of the suburbs. Although it was the first action that he needed to carry out in his project, the engineer added this part after presenting the bulk of the proceedings of his defence first, probably knowing that this part of the project would not be well received by the city. His intention was to put an end to any construction that would be less than four hundred twenty-five metres from the wall of Charles V. (This measure is 600 walking spans, equivalent to $425 \mathrm{~m}$ if we adopt the equivalence of $68.65 \mathrm{~cm}$ for each step given by Prospero Casola [18].) This proposal even affected monastery of San Francisco, or at least the makeup of the walls [19].

He outlined the services needed from the city, including the municipality, other workers, residents of the villages and other necessary trades. Just as had happened in previous years and as was customary in writing proposals, Antonelli established a benefit plan to carry out the work with the least expense and greatest collaboration of city residents [20], among which included rural areas and the poor. This encompassed one thousand three hundred houses and was proposed that every thirteen days, one hundred men would work in the fort. A total of eighteen days in eight months [21]. (Something similar happened in parallel in Cartagena. In 1570 it was ordered that all residents devote two days a week to working on the construction of the walls, and a fine of 300 maravedis per defiance [20].)

After explaining how the people should work on fortifications, the work was budgeted for. As what usually occurred in many other projects, the budget was not what was needed. Antonelli works were budgeted at just over ten thousand pounds, when the project really was over eighty thousand [22]. The works went on to be developed at various stages for eight years [23].

As expected, the day after the arrival of Juan Bautista Antonelli's memorial, on the January 24,1563 , the city council wrote to the king and the signatories of the document to show their absolute rejection of the plans. "... the city cannot possibly undertake the fortifications under the given trace and only has enough to pay $1250 F$ for ammunition" [24].)

With everything shown by Antonelli, we can establish a hypothesis that the design must have their project. The biggest question was to understand the distance between the wall of Charles $\mathrm{V}$ and the new one proposed by Antonelli. It may be that the raised defences were located next to the ancient walls and the proposal was to simply modernise its towers, but by naming the building of new barrages between them, we have thought that the existing enclosure was exempt. Before the presence of the Canicia channel, the barrage strongholds in the west are thought to have been on the left of the channel. Their analysis outlines many similarities within the waterfront with the design that Borçano Ambrosio proposed a century later, with a strong overlap in the stronghold of the bastions and the half 
bastions of San Andrés and San Sebastián. The bastion of San Felipe could be identified with the Santo Domingo platform, also called San Bartolomé, or even as we have already discovered in the future bastion of San Carlos . Through all these, we can hypothesise the designs by Antonelli to be at the forefront of fortifications that remain in Alicante through the 1688 draft fortification plan by José Castellón and Pedro Juan Valero (see Figure 3). Valero y Castellón embodied a design by a previous project engineer Borçano Ambrosio and the draft Borçano of a bastion at the door and another at the half wall at Esperón tower is shown. Amid the barrage that joined, there was a new half stronghold which corresponds with those described by Antonelli at the waterfront. We have chosen not to include the design in the new exhibition by Castellón and Valero to avoid confusion about the suburbia areas caused by the two designs.

The proposed demolition of the San Francisco and San Antón suburb had caused controversy and immediately called for the king to reject the plans. The letter is a clear example of the reality experienced by the Alicante citizens who were tired of supporting the abundance of fortifications, but not willing to admit that Antonelli had underestimated the works. As well as this, the new fortification project included the demolition of a large number of homes. After the first part of the written letter listing predominantly economic reasons for not implementing fortification, it was passed highlighting the events of the last three decades as a justification.

The city had designed its fortification according to the designs of the Duke of Calabria, even though it took an excessively long time. Spending had already risen to fifty thousand ducats, and in later years, Calvi only visited the city to simply give them guidelines on raising the sea line ten or twelve spans and on finishing the tower at the dock door. Therefore, it was not understood why a few years later Antonelli proposed such an ambitious project.

The three areas of the Valencian Parliament met in 1564 again to protest to King Filipe II [1, p. 64]. The reality was that in other cities where they were taking similar step, controversy was also rife. Advances in artillery were much greater than the completion times of the defence improvement works, and this meant the gap between the works of Alicante and new defensive fortification architecture was remarkable and that the modern fortifications involved a cost much higher than their predecessors. (It is worth noting Arciniega's comparison of the construction of the Santa Pola castle - comprising of 134 very thick boundary wall styles with modern bastions, a cost which amounted to 23,000 ducats-, with that of the walls of Cullera whose seven style towers cost was 11,000 ducats [25].)

The request was well received by Felipe II, who decided to reverse his plans for Alicante and focused efforts in the works of the castle and pier. Probably signalling a new stance of the Spanish Empire in the Mediterranean and the risk of attack on the Alicante port had reached its peak, changing the King's plans. (The revolt in the Netherlands in the 1560s diverted a significant proportion of wool export from the Atlantic to the port of Alicante that was heading to France and Italy. The deterioration of Franco-Spanish relations during the French Wars of Religion made the port of Alicante_one of the leading exporters of wool in the late sixteenth century [26].) The siege of Malta in 1565 and later the Battle of 


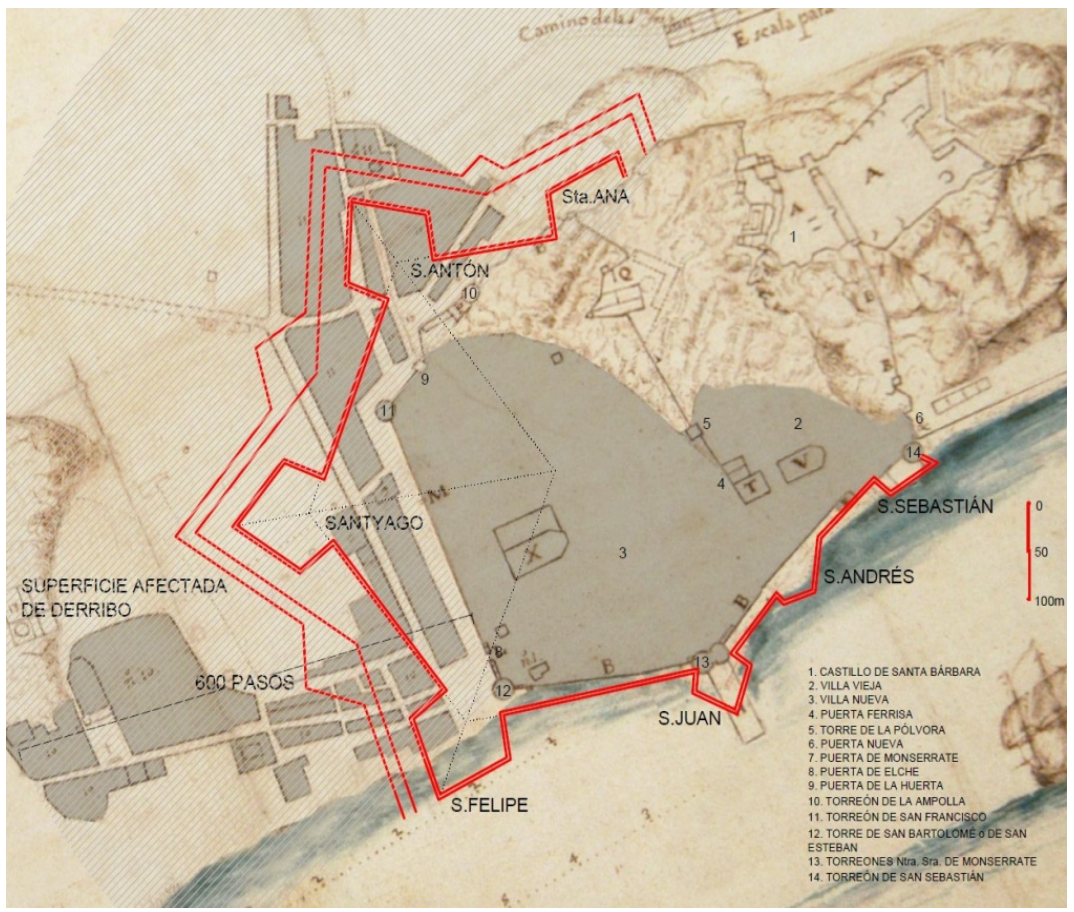

Figure 3: The red line is Antonelli's hypothesised design of 1563, over that of Castellón and Valero of 1688.

Lepanto in 1571 reversed the course of the proceedings in the last quarter century. National unity was strengthened and it became increasingly clear that the strategic importance of the castle of Santa Barbara, but the loss meant leaving free access to Castilla by Vinalopó.

Continuous attacks on the coasts in the kingdom remained a concern for the monarchy. Proof of this came in 1570 when Felipe II ordered Vespasian Gonzaga and Juan Bautista Antonelli to visit the Valencia and Murcia coast. Both proposed a guard system, based on towers located at strategic points for surveillance of coastal defences [27-31]. After the problems arising from citizens of Alicante of Antonelli's projects, and considering the great confidence Felipe II had in Fratín, it was decided that the work would be postponed until the project engineer had prepared a report. Afterwards, the best would be chosen, which was reflected in two letters from the Marquis of Mondejar addressed to the king on 19 December 1574 [32].

On 20 December Fratín went to the castle accompanied by Captain Pedro de Velasco [33], and paid particular attention to the fortification because the viceroy considered it extremely important [34]. To Fratín, his only concern was with the defence of the castle, the last stronghold. In our view he again expressed his inclination to solve this problem in a quick and efficient manner, keeping in truth to his policy of maintaining control of the stronghold. Fratín decided that, without 
doubt, the most important thing was to keep Alicante's strength through perfect defences and proposed the necessary work. After the bitter dispute between Fratín and Gonzaga in the late sixteenth century on the modernisation of the defensive structure of the castle, two half bastions and pliers were built, apparently by Fratín [35].

\section{Conclusions}

As would happen with all projects undertaken by military fortification engineers throughout the sixteenth, seventeenth and eighteenth centuries, the draft Antonelli drew up was not carried out. The defence was put on the backburner because of the importance of the castle, which was considered the last stronghold. The two bastions and the pilers meant Fratín became the first visionary of the fortification bastion of Alicante and showing the first draft bastion fortification of the city of Alicante, by Juan Bautista Antonelli, was dismissed.

\section{References}

[1] Rosser Limiñana, P., Origen y Evolución de las Murallas de Alicante, Ayuntamiento de Alicante, Conselleria de Cultura, Educació i Ciencia, Generalitat Valenciana, Alicante, 1990.

[2] Pardo Molero, J. F., "Proyectos y obras de fortificación en la Valencia de Carlos V", in Estudis: Revista de Historia Moderna, 28, 2000, pp. 137-176, p. 171.

[3] SGE. $\mathrm{CH}$ n 287.1688.

[4] Diccionario histórico, ó Biografía universal compendiada, Librería de Narciso Oliva, Barcelona, 1830, Tomo I, pp. 450-451.

[5] Boira Maiques, J. V., "Geografía i control del territorio. El coneixement i la defensa del litoral valencà al segle XVI: L'enginyer Joan Baptista Antonelli”, in Cuadernos de Geografia, Valencia, 1992, n 52, pp. 184-185.

[6] AGS. Guerra Antigua. Leg. 72. Cfr. Cámara Muñoz, A., Arquitectura y sociedad en el Siglo de Oro: idea, traza y edificio, El Arquero, Madrid, 1990, p. 90.

[7] AGS. Guerra Antigua. Leg. 70. Fol. 165.

[8] AGS. Estado. Leg. 329-I. Fol. 15.

[9] Report Antonelli in 1562. AMA. Arm. 1. Lib. 9. Fols. 66 y ss.

[10] AMA. Arm. 1. Lib. 11. Libro de Privilegios y Provisiones Reales de la Ciudad de Alicante desde el año 1561 asta 1568. Fol. 7.

[11] "Memoria para la fortificación de alicante hecho por Juan Baptista Antoneli Ingeniero de su Magd. a los de la dicha ciuda (...)”. AMA. Arm 1. Lib. 11. Libro de Privilegios y Provisiones Reales de la Ciudad de Alicante desde el año 1561 asta 1568. Fols. 14-17.

[12] AMA. Libro de Privilegios y Provisiones Reales de la Ciudad de Alicante desde el año 1508 asta 1579. ARM 1. Libro 9. Fol. 215.

[13] AMA. Arm 1. Lib. 11. Libro de Privilegios y Provisiones Reales de la Ciudad de Alicante desde el año 1561 asta 1568. Fols. 14-17. 
[14] Bar-Le-Duc, J. E., La fortification démonstrée et reduite en art par feu, Paris, 1583; Le premier livre des instruments mathématiques mécaniques. La fortification réduicte en art et démonstrée. Paris, 1600.

[15] Rojas, C., Teorica y Practica de fortificacion (...) conforme las medidas y defensas destos tiempos, repartida en tres partes. Por el Capitan Cristobal de Rojas, Ingeniero del Rey nuestro Señor. Dirigida al Principe nuestro Señor Don Felipe III. Madrid. Capítulo Primero, de las cosas que son necesarias para la fortificacion. Madrid. 1598. Fol 39 y 69.

[16] AMA. Arm 1. Lib. 11. Libro de Privilegios y Provisiones Reales de la Ciudad de Alicante desde el año 1561 asta 1568. Fols. 14-17.

[17] AMA. Arm 1. Lib. 11. Libro de Privilegios y Provisiones Reales de la Ciudad de Alicante desde el año 1561 asta 1568. Fols. 14-17.

[18] Tous Melia, J. (ed.), Visita de las yslas y reyno de la Gran Canara: Study and manuscript, vol. 1, Museo Militar Regional de Canarias, 2000, p. 38.

[19] AMA. Arm 1. Lib. 11. Libro de Privilegios y Provisiones Reales de la Ciudad de Alicante desde el año 1561 asta 1568. Fols. 14-17.

[20] Guimaraens Igual, G., El último hálito de la fortificación abaluartada: el fuerte de San Julián de Cartagena, Tesis doctoral, Departamento de Composición Arquitectónica, E.T.S. Arquitectura de la Universidad Politécnica de Valencia, 2008, p. 1036.

[21] AMA. Arm 1. Lib. 11. Libro de Privilegios y Provisiones Reales de la Ciudad de Alicante desde el año 1561 asta 1568. Fols. 14-17.

[22] Según presupuesto de Jaume Riera, Johan Garra y Pere Borrachero. AMA. Arm. 1. Lib. 11. Libro de Privilegios y Provisiones Reales de la Ciudad de Alicante desde el año 1561 asta 1568. Fols. 9-10v.

[23] AMA. Arm 1. Lib. 11. Libro de Privilegios y Provisiones Reales de la Ciudad de Alicante desde el año 1561 asta 1568. Fols. 14-17.

[24] AMA. Arm. 1. Lib. 11. Libro de Privilegios y Provisiones Reales de la Ciudad de Alicante desde el año 1561 asta 1568. Fols. 11-13v.

[25] Arciniega García, L., "Defensas a la antigua y a la moderna en el Reino de Valencia durante el siglo XVI", en Espacio, Tiempo y Forma, Serie VII, H. del Arte, T. 12. 1999, pp. 61-94, p. 83.

[26] Giménez López, E. "Dos décadas de estudios sobre el comercio valenciano en la edad moderna", in Revista de Historia Moderna: Anales de la Universidad de Alicante, No 6-7, 1986-87. Págs. 193-206. Pág. 197.

[27] AGS. Guerra Antigua. Leg. 177, fol. 29 y 31.

[28] Cámara Muñoz, A.: "Las torres del litoral en el reinado de Felipe II: una arquitectura para la defensa del territorio (y II)", Espacio, Tiempo y Forma, Serie VII, Historia del Arte, t. 4, 1991, pp. 53-94.

[29] Pradells Nadal, J., "La defensa de la costa valenciana en el siglo XVIII: el Resguardo", in Balaguer, E.; Giménez. E. (eds.). Ejército, ciencia y sociedad en la España del Antiguo Régimen, Instituto de Cultura Juan Gil Albert, Alicante, 1995, pp. 241-270.

[30] Pradells Nadal, J., "Transformaciones en la concepción de la defensa de la costa (siglos XVI-XVIII)", in Furió, A; Aparici, J. (eds.). Castells, torres $i$ 
fortificacions en la Ribera del Xúquer, VIII Assemblea d'Història de La Ribera, Ajuntament de Cullera- Universitat de València, 2002, pp. 175-193.

[31] Pradells Nadal, J., "La defensa de las costas valencianas en el siglo XVIII ante el corsarismo y la piratería norteafricanas", in Sánchez Fernández, Ana (coord.), II Congreso Internacional de Estudios Históricos: el Mediterráneo, un mar de piratas y corsarios, 2002, pp. 135-159.

[32] AGS. Guerra Antigua. Leg. 78, fol. 22.

[33] AGS. Guerra Antigua. Leg. 78. Fol. 34. Copia de la Carta del fratín para el marqués de mondéjar fecha en alicante a XX de diziembre de 1574.

[34] AGS. Guerra Antigua. Leg. 78. Fol. 33. Carta de D. Pedro de Velasco al marqués de Mondéjar de 21 de diciembre de 1574.

[35] Echarri Iribarren, V., Pérez Millán, M. I., \& González Avilés, Á. B., "La competitividad de Vespasiano Gonzaga y el Fratín sobre la modernización de las estructuras del castillo de Alicante en la segunda mitad del siglo XVI", in Concursos de arquitectura: 14 Congreso Internacional Expresión Gráfica Arquitectónica. Oporto (Portugal), Portugal mayo de 2012. ISBN 978-84-8448-708-1. 